\title{
Empirical study of Indonesian SMEs sales performance in digital era: The role of quality service and digital marketing
}

\section{Arifin Djakasaputra ${ }^{a^{*}}$, Oscarius Yudhi Ari Wijaya ${ }^{\mathrm{b}}$, Andrew Shandy Utama ${ }^{\mathrm{c}}$, Corry Yohana ${ }^{\mathrm{d}}$, Buyung Romadhoni $^{\mathrm{e}}$ and Mochammad Fahlevi ${ }^{\mathrm{f}}$}

\author{
${ }^{a}$ First Author: Lecture, Universitas Tarumanagara, Jakarta, Indonesia \\ ${ }^{b}$ Lecture, Akademi Sekretari Dan Manajemen Indonesia (ASMI) Surabaya, Indonesia \\ ${ }^{c}$ Lecture, Universitas Lancang Kuning Indonesia \\ ${ }^{d}$ Lecture, Universitas Negeri Jakarta, Indonesia \\ ${ }^{e}$ Lecture, Universitas Muhammadiyah Makassar, Indonesia \\ ${ }^{f}$ BINUS Online Learning, Bina Nusantara University, Jakarta, Indonesia

\section{H R O N I C L E \\ A B S T R A C T}

Article history:

Received: March 01, 2021

Received in revised format: April

6, 2021

Accepted: May 31, 2021

Available online: June 2, 2021

Keywords:

Digital marketing

Quality service

Sales performance

SMEs

\begin{abstract}
This research aims to analyze the relationship between digital marketing on quality service, digital marketing on sales performance, quality service on sales performance, and digital marketing on Sales performance through quality service. The research methodology is a quantitative method and divided into research design and research subjects, data collection methods, and analysis methods. The study is conducted on 125 small and medium (SMEs) in Banten, Indonesia in the digital region. The study uses primary data based on the results of distributing online questionnaires to 125 managers of SMEs in Banten who were selected by simple random sampling. The questionnaire was designed online, and each question/statement item was given five answer options, namely: strongly agree (SS) score 5 , agree (S) score 4, neutral / doubt (N) score 3, disagree (TS) score 2, and strongly disagree (STS) score 1 . The method for processing data is by using PLS and using SmartPLS version 3.0 software. Based on data analysis by SmartPLS, digital marketing has a significant effect on quality service, digital marketing has a significant effect on sales performance, quality service has a significant effect on sales performance, and digital marketing significantly affects sales performance through quality service in the digital era.
\end{abstract}

C 2021 by the authors; licensee Growing Science, Canada.

\section{Introduction}

In the era of the industrial revolution 4.0 and the digital era, the level of development of information technology is growing rapidly. According to Aggarwal et al. (2021); Alzaam et al. (2021) and Amri et al. (2021), SMEs have a contribution of 60.3\% of Indonesia's total gross domestic product (GDP). In addition, MSEs absorb $97 \%$ of the total workforce and $99 \%$ of the total employment. In 2018, UMKM recorded as many as 64.2 million units and took advantage of various small to large business activities and development to run its business. The number of competitors is taken into consideration for entrepreneurs to enter inside very fierce competition. Strategy appropriate marketing and media to be able to reach the target market so always increasing sales volume and profit. Digital Marketing is a medium marketing that is currently in great demand by the community to support various activities performed. According to Kartika et al. (2020) with digital marketing communications and transactions can be done any time / real time and can be global or global. With the number of chat-based social media users increasing day by day, open opportunities for SMEs to develop their market deep smartphone grip. Surveys conducted throughout 2021 found that 132.7 million people in Indonesia are connected to the internet. The total population of Indonesia is 256.2 million people.

* Corresponding author.

E-mail address: $\underline{\text { arifind@fe.untar.ac.id (A. Djakasaputra) }}$ 
In supporting these activities, many SMEs are already using quite modern smartphones. Apparently, they also knew and carried out marketing activities to make use of these smartphones. Communication is done with direct calls, SMS (short message send), and have started using social media to make an offer like BBM (Blackberry Messenger), FB (Facebook), WA (WhatsApp), IG (Instagram). According to Asbari et al. (2021), Affandi et al. (2020) and Budi et al. (2020) social media is a part of digital marketing used, delivers influence on the sales volume of SMEs. Turban et al. (2004), explained that online shopping is the activity of purchasing products (both goods and services) via the internet. Activities online shopping includes Business to activities Business (B2B) and Business to Consumers (B2C). Meanwhile, on research activities, online shopping is associated with $\mathrm{B} 2 \mathrm{C}$ because the intended purchasing activity is purchasing activities used by consumers themselves, not resale. According to Fahmi et al. (2021), the online shopping activity here is a retail transaction with individual buyers, So here is a shopping online purchase decision made by individuals online. Digital marketing aims to achieve various goals such as the following: Increase market share. Increase the number of comments on a blog or website. Upgrade sales revenue. Reducing costs (e.g., distribution or promotion costs). Achieve brand goals (such as increasing brand awareness). Increase database size. Reach Customer Relationship Management (CRM) objectives (such as increasing customer satisfaction, frequency of purchase, or reference level customer). Improve management of the supply chain (such as by increasing coordinating members, adding partners, or optimize inventory levels). E-marketing is a development of traditional marketing where traditional marketing is a marketing process through offline communication media such as brochures, advertisements on television and radio. After the rise of the internet and the ease of communication it offers, then the application of marketing in companies began to adopt the internet media, which was later referred to as e-marketing. Saad and Alsheri (2021) internet marketing have five major advantages for companies that use it. First, both small companies and large companies can do it. Second, there are no limits real in the advertising space when compared to print and broadcast media. Third, access and information retrieval is very fast when compared to express mail or even fax. Fourth, the site can be visited by anyone, anywhere in the world, at any time. Fifth, shopping can be done more quickly and alone. Techniques that facilitate access and publication of information using social interaction via social media. According to Bernarto et al. (2020); Fahmi et al. (2020), and Hartono and Maksum (2020), there are two types of marketing, namely offline marketing or traditional marketing that is done with find customers or clients through online meetings with those who may be interested in becoming customer or client. Other marketing uses the website as a marketing medium which is known as online marketing. From a business point of view, social media is all about making conversation possible. According to Lukman et al. (2021), social media is also about how these talks can be generated, promoted, and turned into income. Social media is a place, a tool, a service that allows individuals to express themselves to meet and share with other colleagues through internet technology. Social media is a phase of change in how people discover, read, speak and share information, news, and data. Social media has become very popular because of its simplicity and opportunity for people to connect online in the form of personal relationships, politics and business activities. Social media provides social communication services. Referring to the background above, in general, the problem formulation is how to implement digital marketing, is it influential in increasing the sales volume of the home industry. According to Ismaya et al. (2020), Leu and Masri (2021), and Muafi et al. (2021). Many things affect the increase in sales volume, promotion, advertising, product quality, price and others. Besides that, there is also digital marketing, social media, and search engine optimization (SEO). In this study, the authors only limit the social media users. SMEs that can affect increasing sales volume. This research aims to analyze the relationship between digital marketing on quality service, digital marketing on sales performance, quality service on sales performance, and digital marketing on Sales performance through quality service. In general, the benefits of research are finding out if digital marketing can impact the increase in sales volume of SMEs. For SMEs managers can be a new discourse in order increasingly innovating in marketing results home industry.

\section{Method}

This research methodology is divided into research design and research subjects, data collection methods, and analysis methods. This research is a quantitative study on $125 \mathrm{SMEs}$ in Banten, Indonesia. This study uses primary data which was obtained based on the results of distributing online questionnaires to 125 managers of SMEs in Banten who were selected by simple random sampling. The questionnaire was designed online, and each question/statement item was given five answer options, namely: strongly agree (SS) score 5, agree (S) score 4, neutral / doubt (N) score 3, disagree (TS) score 2, and strongly disagree (STS) score 1. The method for processing data is by using PLS and using SmartPLS version 3.0 software. According to Hair et al. (2012) The measurement model testing phase includes testing for convergent validity and discriminant validity. For construct reliability in this study, composite reliability and Cronbach's alpha value were used. This research method is adopted from Asbari et al. (2021); Bernarto et al. (2020); Fahmi et al. (2020) and Hartono and Maksum (2020): Ismaya et al. (2020); Priadana et al. (2021) ; Purwanto et al. (2021) Quddus et al. (2020) Yunarsih et al. (2020) and Wanasida et al. (2021). If all indicators in the PLS model have satisfied the standards of convergent validity, discriminant validity, and reliability testing, the findings of the PLS analysis may be utilized to assess the study hypothesis. The loading factor value of each indicator is compared to the concept during the convergent validity test phase. For factor weights of 0.5 or greater, it is deemed to have enough good validation to explain latent constructs, according to Naushad (2021); Nugroho et al. (2020); and Nguyen et al. (2021). The approved loading factor in this study is 0.5, if the AVE value of each construct is more than 0.5. Several indications or elements must be eliminated from the model after SmartPLS 3.0 processing, according to Hair et al. (2018). Furthermore, all indicators have a loading factor more than 0.5 , or the AVE value is more than 0.5 . This study model's convergent validity satisfies the standards. Discriminant validity is used to verify that each latent variable's idea is distinct from that of 
other latent variables. According to Hair et al. (2017), the model has strong discriminant validity if the AVE square value of each exogenous construct on the weight on the diagonal surpasses the correlation between that construct and the other constructs (values below the diagonal). Based on previous research and literature review, a hypothetical model is drawn as follows:

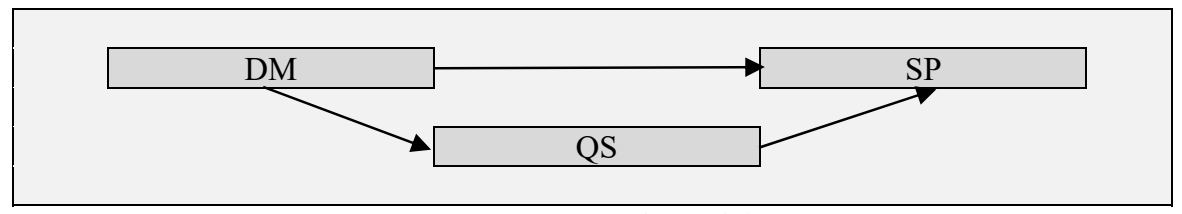

Fig. 1. Research Model

Digital marketing (EM), Quality service (QS), Sales performance (SP)

Based on the problems and previous research, the following hypotheses were obtained:

$\mathbf{H}_{1}$ : Digital marketing (DM) has a positive effect on Quality service (QS).

$\mathbf{H}_{2}$ : Digital marketing (DM) has a positive impact on Sales performance (SP).

H3: Quality service (QS) has a positive impact on Sales performance (SP).

H4: Digital marketing (DM) has a positive effect on Sales performance (SP) through Quality service (QS).

Digital marketing variables are as follows: Transaction / Cost is a promotional technique with a high level of efficiency to reduce transaction costs and times. Incentive Program, interesting programs are certainly an advantage in every promotion that is carried out. These programs are also expected to provide more value to the company. Site Design is an attractive appearance in digital marketing media that can positively value the company. Interactive, is a two-way relationship between the company and consumers who can provide information and can be received well and clearly.

\section{Result and Discussion}

\subsection{Test Results of the Validity and Reliability of Research Indicators}

According to Hair et al. (2012), the results of discriminant validity testing are by using the AVE square value. The results of the discriminant validity test shown in Table 1 show that all constructs have an AVE square root value above the correlation value with other latent constructs. Likewise, the cross-loading value of all items from an indicator is greater than the other indicator items, so it can be concluded that the model has met discriminant validity.

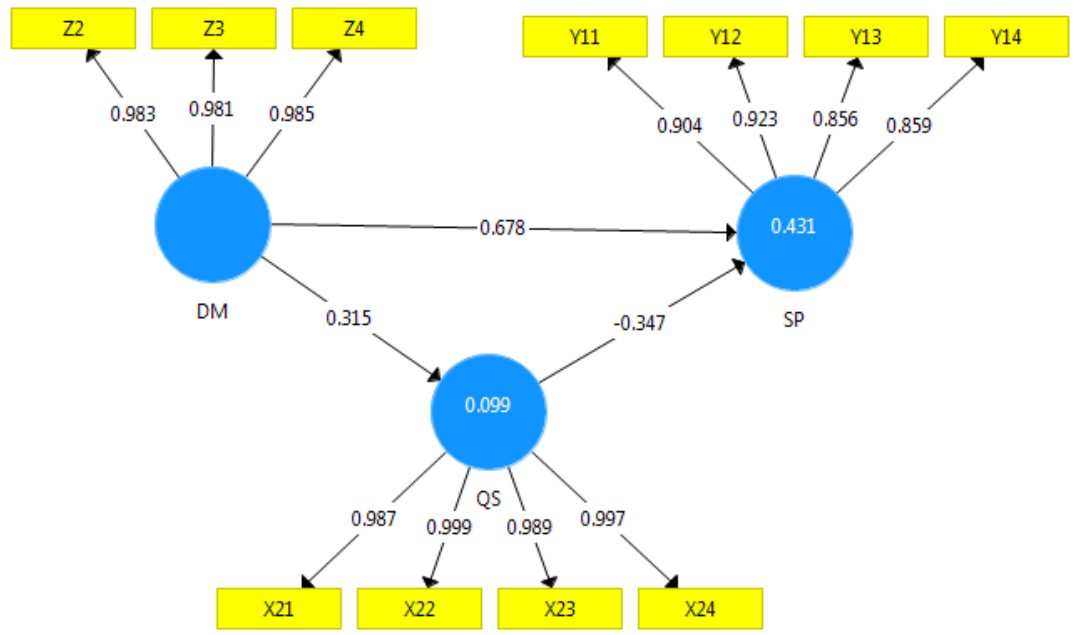

Fig. 2. Convergent Validity Testing

Based on the estimation results of the PLS model in the picture above, all indicators have a loading factor value above 0.5 so that the model has met the convergent validity requirements. Apart from looking at the loading factor value of each indicator, convergent validity was also assessed from the AVE value of each construct. According to Hair et al. (2018), the AVE value for each construct of this study is more than 0.5 . So the convergent validity of this research model has met the requirements. The value of loadings, Cronbach's alpha, composite reliability, and AVE for each complete construct can be seen in Table 1 and Fig. 2. 
Table 1

Cronbach's Alpha, Composite Reliability, and Average Variance Extracted (AVE)

\begin{tabular}{lcccc}
\hline & Cronbach's Alpha & rho A & Composite Reliability & (AVE) \\
\hline DM & 0.982 & 0.983 & 0.988 & 0.966 \\
QS & 0.995 & 0.999 & 0.997 & 0.986 \\
SP & 0.91 & 0.926 & 0.936 & 0.785 \\
\hline
\end{tabular}

The construct reliability value can be assessed from the Cronbach's alpha value and the composite reliability of all constructs. The recommended composite reliability and Cronbach's alpha value is more than 0.7 . The reliability test results in Table 2 above show that all constructs have composite reliability and Cronbach's alpha values greater than 0.7 ( $>0.7)$. In conclusion, all constructs have met the required reliability.

\subsection{Construction Reliability Testing}

According to Hair et al. (2018), Cronbach's alpha value and the composite reliability of each construct may be used to measure construct reliability. More than 0.7 is suggested for composite reliability and Cronbach's alpha (Asbari, 2020). The reliability test findings in Table 1 reveal that all constructs are compositely reliable, with Cronbach's alpha values larger than 0.7 ( $>0.7)$. Finally, all constructions have achieved the requisite level of dependability. Discriminant validity is used to verify that each idea of each latent variable is distinct from other latent variables, according to Hair et al. (2012). If the AVE square value of each exogenous construct (the value on the diagonal) surpasses the correlation between this construct and other constructs, the model has excellent discriminant validity. The discriminant validity test findings demonstrate that all constructs have a square root value of AVE greater than the correlation value with other latent constructs (as determined by the Fornell-Larcker criterion), implying that the model is discriminately valid. The effect test was performed using the t-statistic test in the partial least squared (PLS) analysis model using the SmartPLS 3.0 software. With the bootstrapping technique, the R Square value and the significance test value are obtained as shown in the table below:

Table 2

$\underline{\text { R Square }}$

\begin{tabular}{ccc}
\hline & R Square & R Square Adjusted \\
\hline QS & 0.099 & 0.095 \\
SP & 0.431 & 0.427 \\
\hline
\end{tabular}

Based on Table 2 above, the R Square value for quality service is 0.099 , which means that quality service variable can be explained by digital marketing is $9.9 \%$, the value of $\mathrm{R}$ Square for sales performance is 0.431 , which means that sales performance variable can be explained by e- digital marketing and quality service variable by $43.1 \%$.

\subsection{Hypothesis testing}

According to Hair et al. (2012) hypothesis testing in PLS is the inner model test. This test includes a significance test for direct and indirect effects as well as a measurement of the magnitude of the influence of exogenous variables on endogenous variables. To determine the effect of transformational leadership on employee performance through a ready-to-change mentality as a mediating variable, a direct and indirect effect test is needed. According to Hair et al. (2018), the effect test was performed using the t-statistic test in the partial least squared (PLS) analysis model using the SmartPLS 3.0 software. With the bootstrapping technique, the R Square value and the significance test value were obtained as shown in Tables (2-3).



Fig. 2. Hypotheses Testing 
The results of hypothesis testing for all variables that have a direct effect are shown in Table 3 as follows,

Table 3

Hypothesis Result of the Structural Model

\begin{tabular}{|c|c|c|c|c|}
\hline Hypothesis & Standardized Path Coefficient $(\beta)$ & t-value & P Value & Test Result \\
\hline $\mathrm{H} 1: \mathrm{DM} \rightarrow \mathrm{QS}$ & 0.412 & $4.338^{* *}$ & 0.000 & Supported \\
\hline $\mathrm{H} 2: \mathrm{DM} \rightarrow \mathrm{SP}$ & 0.031 & $11.594 * *$ & 0.000 & Supported \\
\hline H3: QS $\rightarrow$ SP & 0.0685 & $9.401 * *$ & 0.000 & Supported \\
\hline $\mathrm{H} 4: \mathrm{DM} \rightarrow \mathrm{QS} \rightarrow \mathrm{SP}$ & & $3.634 * *$ & 0.000 & Supported \\
\hline
\end{tabular}

\section{H1: Digital marketing (DM) havs a positive effect on Quality service (QS).}

Data analysis by SmartPLS shows the result of the $\mathrm{p}$ value is significant $\mathrm{p}$ value is $0.000<0.050$, and $\mathrm{T}$ value is $4.338>1.96$ which means Digital marketing (DM) has significant effect on Quality service (QS). This means that an increase in Digital marketing (DM) will encourage Quality service (QS). and a decrease in Digital marketing (DM) will encourage a decrease in Quality service (QS). The results of this study are aligned with Pramono et al. (2021); Prameswari et al. (2020) and Praditya (2020) states that Digital marketing (DM) has significant effect on Quality service (QS).

\section{H2: Digital marketing (DM) has a positive effect on Sales performance (SP).}

Data analysis by SmartPLS shows the result of the $\mathrm{p}$ value is significant $\mathrm{p}$ value is $0.000<0.050$, and $\mathrm{T}$ value is $11.594>$ 1.96 which means Digital marketing (DM) has significant effect on Sales performance (SP)This means that an increase in Digital marketing (DM) will encourage Sales performance (SP) and a decrease in Digital marketing (DM) will encourage a decrease in Sales performance (SP). The results of this study are aligned with Priadana et al. (2021); Purwanto et al. (2021) and Pham et al. (2021) states that Digital marketing (DM) has a significant effect on Sales performance (SP).

\section{H3: Quality service (QS) has a positive effect on Sales performance (SP).}

Data analysis by SmartPLS shows the result of the $\mathrm{p}$ value is significant $\mathrm{p}$ value is $0.000<0.050$, and $\mathrm{T}$ value is $9.401>1.96$ which means Quality service (QS) has a significant effect on Sales performance (SP). This means that an increase in Digital marketing (DM) will encourage Sales performance (SP) and a decrease in Quality service (QS) will encourage a decrease in Sales performance (SP). The results of this study are aligned with Quddus et al. (2020); Rahaman et al. (2021) and Singhdong et al. (2021) states that Quality service (QS) has significant effect on Sales performance (SP).

\section{H4: Digital marketing (DM) has a positive effect on Sales performance (SP) through Quality service (QS).}

Data analysis by SmartPLS shows the result of the $\mathrm{p}$ value is significant $\mathrm{p}$ value is $0.000<0.050$, and $\mathrm{T}$ value is $3.634>1.96$ which means Digital marketing (DM) has a significant effect on Sales performance (SP) through Quality service (QS). This means that an increase in Digital marketing (DM) will encourage Sales performance (SP) through Quality service (QS)and a decrease in Digital marketing (DM) will encourage a decrease in Sales performance (SP) through Quality service (QS). The results of this study are aligned with Suheny et al. (2020); Syafri et al. (2021) and Tan et al. (2021) state that Digital marketing (DM) has significant effect on Sales performance (SP) through Quality service (QS).

\subsection{Discussion}

According to Yunarsih et al. (2020) and Wanasida et al. (2021), the most used social media are Facebook, Twitter and Instagram. For most MSMEs, knowing the benefits of using social media are for personal communication with consumers, marketing, and advertising, recording consumer needs, responding to consumers, helping decision making and as a forum for discussion with consumers. The study found that the use of internet marketing allows companies to communicate with their products that have a positive impact on their performance. According to Alzaam et al. (2021) and Amri et al. (2021) Companies can improve their customer relationships using internet marketing and advertise their products and track their sales more easily. The development of information technology can open opportunities for MSMEs to take advantage of social media as a cheap and effective promotional media. If managed properly, social media is proven to be an effective promotional media and can increase market share. Based on the above research results, the application of Digital Marketing through Fan Pages to target the target market in the micro businesses industry. According to Affandi et al. (2020) and Budi et al. (2020) the Transaction / cost dimension shows the ability of digital marketing at MSMEs to reduce business promotion costs with a high level of efficiency because digital marketing can save costs. Digital marketing reduces conventional promotional costs. With the development of information technology, the use of social media in the context of the transaction process is getting easier and will make MSMEs more effective in reaching a wider target market. With the help of digital marketing, customers will 
find out for themselves about the products offered by MSMEs. Indirectly this will have an impact on time efficiency for customers. Customers do not need to come to the store first to find out information on the products offered, because this information can already be seen on various social media platforms used by MSMEs as promotional media. According to Nugroho et al. (2020) and Nguyen et al. (2021) digital marketing for MSMEs feels time efficient in transactions. This is because the digital marketing system is very developed in all aspects of payment with various payment options. An example is the payment facility provided by an online ordering application. According to Priadana et al. (2021); Setiawati et al. (2021) and Dharmayuni et al. (2021) digital marketing has helped employees and entrepreneurs explain the products and services that MSMEs have. Digital marketing helps employees and employers explain products and services, this shows that employees and employers agree that digital marketing helps provide clear information. The social media platforms that SMEs use can assist employees or employers in providing explanations of information about the products offered by SMEs, so that employees can be optimized for other jobs. According to Leu and Masri (2021) and Muafi et al. (2021) the use of social media for SMEs is very useful, among others, as a means of direct contact with order, to promote the work of home industry, data consumer desires, convey a response to consumers and as a basis for taking decisions in transactions. Besides being social, the media is also useful as a discussion forum online, monitoring customer progress, customer surveys, recording needs of distributors / agents, and displaying product photos. SMEs managers feel that way great benefits obtained by using social media as a means of selling the products of the home industry. According to Purwanto et al. (2021) and Pham et al. (2021) Social media is one of the driving elements for SMEs to continue using in developing products, doing communication with consumers and customers, distributors, as well as developing market networks a wider range, thus increasing greater sales volume. Social media is a place, a tool, a service that allows individuals to express themselves to meet and share with other colleagues via internet technology. Social media is a phase change in how people find, read, talk, and share information, news, data to others. According to Priadana et al. (2021); Setiawati et al. (2021) and Dharmayuni et al. (2021) social the media became very popular because of this ease and provide opportunities to people to be able to connect online in the form of personal relationships, politics, and business activities. Social media provides social communication services. The results of this study indicate that SMEs get an increase in orders from consumers after using social media. Besides, communication is also effective and efficient because it can communicate directly and economically. Then they can also develop a bigger business because they can transact directly and payments can also be transferred, besides being able to develop their business with agents / distributors, social media results in an increase in sales volume due to sales volume assessments. The role of the internet in the business world which is very significant is the changing concept of marketing carried out by companies. According to Ismaya et al. (2020); Leu and Masri (2021) and Muafi et al. (2021) companies began to use the internet as a promotional tool throughout the world by creating an official company website. According to Quddus et al. (2020); Rahaman et al. (2021) and Singhdong et al. (2021) company websites generally present a company profile, products sold and news regarding company activities. The company also provides email information to the public who will communicate with the company. Not only big companies but even small companies have a site because creating a site is not difficult and the cost is relatively affordable. The difference is in the management of the site, where in large companies it is managed specifically so that the data and appearance are frequently updated. The internet is also used as a medium to get potential customers by sending emails and newsletters, which in Philip Kotler's marketing theory is an example of direct marketing via the internet. One type of marketing that utilizes various media on the internet is viral marketing or viral marketing. Viral marketing is a word-of-mouth marketing model using the Internet media or the Internet Word of Mouth. Viral means a virus that spreads quickly.

\section{Conclusion}

Based on data analysis by SmartPLS, digital marketing has significant effect on quality service, digital marketing has significant effect on sales performance, quality service has significant effect on sales performance, digital marketing has significant effect on Sales performance through quality service. SMEs use social media as a vehicle for business operations. The most widely used social media are Facebook (FB), WhatsApp (WA), Instagram (IG). The benefits are most felt is that communication with the customers and suppliers are more intestinal as well as effective and efficient because it can communicate 24 hours direct or real time. Process transactions are easier and cheaper because the media communication only costs pulses to support communication. Promotion media the best because it can display and share images via media to the community and public. Information updates can be done every time. And most importantly, the average sales volume increased. SMEs are suggested to optimize technological developments with the information available to the maximum. He started doing new innovations in ways promoting the results of his home industry to make it more interesting by taking advantage of social existing media to increase the volume sales can continue to increase and develop.

\section{Reference}

Aggarwal, K., Malik, S., Misshra, D. K., \& Paul, D. (2021). Moving from Cash to Cashless Economy: Toward Digital India. The Journal of Asian Finance, Economics and Business, 8(4), 43-54. https://doi.org/10.13106/JAFEB.2021.VOL8.NO4.0043

Alzaam, A. F., \& Almizeed, K. (2021). The effect of digital marketing on purchasing decisions: A case study in Jordan. The Journal of Asian Finance, Economics and Business, 8(5), 455-463. https://doi.org/10.13106/JAFEB.2021.VOL8.NO5.0455 
Amri, W. A. A., Asbari, M., Gazali, G., Novitasari, D., \& Purwanto, A. (2021). The effect of religiosity and service quality on job satisfaction: A case study of MSME employees. International Journal of Social and Management Studies, 2(1), 53-63. https://doi.org/10.5555/ijosmas.v2i1.7

Asbari, M., Dylmoon Hidayat, D., \& Purwanto, A. (2021). Managing Employee Performance: From Leadership to Readiness for Change. International Journal of Social and Management Studies, 2(1), 74-85. https://doi.org/10.5555/ijosmas.v2i1.12

Affandi, A., Sarwani, Sobarna, A., Erlangga, H., Siagian, A. O., Purwanto, A., Effendy, A. A., Sunarsi, D., Wicaksono, W., Suyatin, Ariyanti, E., Wahyitno, Manik, C. D., Juhaeri, \& Gunartin, (2020) Optimization of MSMEs Empowerment in Facing Competition in the Global Market during the COVID-19 Pandemic Time. Systematic Reviews in Pharmacy, 11 (11), 1506-1515. doi:10.31838/srp.2020.11.213

Budi, \& Maksum, I. (2020). The importance of changing management styles in the digital age: The importance of changing management styles in the digital age. Journal of Industrial Engineering \& Management Research, 1(3), 148-154. https://doi.org/10.7777/jiemar.v1i3.75

Bernarto, Bachtiar, Sudibjo, Suryawan, Purwanto \& Asbari (2020). Effect of Transformational Leadership, Perceived Organizational Support, Job Satisfaction Toward Life Satisfaction: Evidences from Indonesian Teachers. International Journal of Advanced Science and Technology, 29(3), 5495 -5503

Dharmayuni, L., Sunarsi, D., Sembiring, E., Satata, S., Bahrudin, U., \& Purwanto, A. (2021). Effect of distribution cost and promotion cost on tire industries sales performance. Annals of the Romanian Society for Cell Biology, 25(2), 12672-12684

Fahmi, K., Kurniawan, T., Cahyono, Y., Sena, A., Suhadarliyah, Suryani, P., Sugianto, A., Amelia, D., Musnaini, Amin, S., Hasbullah, H., Jihadi, M., Wijoyo, H. \& Purwanto, A. (2020). Did Servant, Digital and Green Leadership Influence Market Performance? Evidence from Indonesian Pharmaceutical Industry. Systematic Reviews in Pharmacy, 11(9), $642-653$. doi: 10.318

Fahmi, K., Mustofa, A., Rochmad, I., Sulastri, E., Wahyuni, I. S., \& Irwansyah, I. (2021). The Effect of Six Sigma on Quality, Innovation Capability and Work Productivity of Tyre Industries. Journal of Industrial Engineering \& Management Research, 2(1), 1 - 12. https://doi.org/10.7777/jiemar.v2i1.109

Hamid, N., R., Cheng, A., Y., \& Md Akhir, R. (2011). Dimension of E-CRM: an empirical study on Hotles' web sites. Journal of Southeast Asian Research, 2-12.38/srp.2020.9.95

Hair, J. F., Sarstedt, M., Ringle, C. M., \& Mena, J. A. (2012). An Assessment of the Use of Partial Least Squares Structural Equation Modeling in Marketing Research. Journal of the Academy of Marketing Science, 40(3), 414-433.

Hair, J. F., Hult, G. T. M., Ringle, C. M., \& Sarstedt, M. (2017). A Primer on Partial Least Squares Structural Equation Modeling (PLS-SEM). $2^{\text {nd }}$ ed. Thousand Oaks, CA: Sage.

Hair, J. F., Sarstedt, M., Ringle, C. M., \& Gudergan, S. P. (2018). Advanced Issues in Partial Least Squares Structural Equation Modeling (PLS-SEM). Thousand Oaks, CA: Sage

Hartono,B., \& Maksum, I. (2020). The importance of changing management styles in the digital age: The importance of changing management styles in the digital age. Journal of Industrial Engineering \& Management Research, 1(3), 148154. https://doi.org/10.7777/jiemar.v1i3.75

Hur, Y., Ko, Y., J., \& Valacich, J. (2011). A structural model of the relationship between sport website quality, e-satisfaction, and e-loyalty. Journal of Sport Management, 25, 462-465.

Ismaya, B., Setiawan, T., Sulistyarini, I., Winarti, A., Nabila, R., \& Purnamaningsih, I. R. (2020). FAST Leadership Model for University Leaders Performance in Pharmacy Faculty: Yesterday, Today and Tomorrow. Systematic Reviews in Pharmacy, 11(8), 362-373. doi:10.31838/srp.2020.8.54

Kartika, H., Kholil, M., \& Setia Bakti, C. (2020). Service Quality and Customer Satisfaction in Furniture Sector. Journal of Industrial Engineering \& Management Research, 1(2), 103-111. https://doi.org/10.7777/jiemar.v1i2.44

Lukman, L., Sujianto, A. E., Waluyo, A., \& Yahya, M. (2021). Service Quality and Consumer Satisfaction: An Empirical Study in Indonesia. The Journal of Asian Finance, Economics and Business, 8(5), 971-977. https://doi.org/10.13106/JAFEB.2021.VOL8.NO5.0971

Leu, J. F. Y., \& Masri, R. (2021). Omni-Channel Retailing and Digital Business: A Case Study in Malaysia. The Journal of Asian Finance, Economics and Business, 8(4), 403-412. https://doi.org/10.13106/JAFEB.2021.VOL8.NO4.0403

Muafi, M., Syafri, W., Prabowo, H., \& Nur, S. A. (2021). Digital Entrepreneurship in Indonesia: A Human Capital Perspective. The Journal of Asian Finance, Economics and Business, 8(3), 351-359. https://doi.org/10.13106/JAFEB.2021.VOL8.NO3.0351

Naushad, M. (2021). Investigating Determinants of Entrepreneurial Leadership Among SMEs and Their Role in Sustainable Economic Development of Saudi Arabia. The Journal of Asian Finance, Economics and Business, 8(4), $225-237$. https://doi.org/10.13106/JAFEB.2021.VOL8.NO4.0225

Nugroho, B. S., Widdah, M. E., Suryana, A. T., Ibrahim, T., Humaira, M. A., Nasrudin, M., Mubarok, M. S., Abadi, M. T., Adisti, A. R., Gadzalia, S. S., Muqtada, M. R., Purwanto, .A., Fahlevi, M. \& Sudargini, Y. (2020) Effect of Leadership Style Toward Indonesian Education Performance in Education 4.0 Era: A Schematic Literature Review. Systematic Reviews in Pharmacy, 11(10), 371-378. doi:10.31838/srp.2020.10.60

Nguyen, H., Tran, T. H. M., Nguyen. H. Y., \& Truong, D. D. (2021). The Influence of Competitive Advantage on Financial Performance: A Case Study of SMEs in Vietnam. The Journal of Asian Finance, Economics and Business, 8(5), $335-343$. https://doi.org/10.13106/JAFEB.2021.VOL8.NO5.0335 
Pramono, R., Sondakh, L.W, Bernarto , I., Juliana, \& Purwanto, A. (2021) Determinants of the Small and Medium Enterprises Progress: A Case Study of SME Entrepreneurs in Manado, Indonesia. The Journal of Asian Finance, Economics, and Business, 8(1), 881-889. https://doi.org/10.13106/JAFEB.2021.VOL8.NO1.881

Prameswari, M., Asbari, Purwanto,A., Ong, Kusumaningsih, Mustikasiwi, Chidir, Winanti, \& Sopa. (2020). The Impacts of Leadership and Organizational Culture on Performance in Indonesian Public Health: The Mediating Effects of Innovative Work Behavior. International Journal of Control and Automation, 13(02), 216 - 227

Praditya, R. A. (2020). Leadership, Work Motivation, Competency, Commitment and Culture: Which influences The Performance of Quality Management System in Automotive Industry?. Journal of Industrial Engineering \& Management Research, 1(1), 53-62. https://doi.org/10.7777/jiemar.v1i1.27

Priadana, S., Sunarsi, D., Wahyitno, A. P. S., Mogi, A., Agustin, F., Irawati, L., ... \& Purwanto, A. (2021). The Effect of Strategic Leadership on Competitive Strategy and Business Performance: Evidence from Indonesian SME's. Annals of the Romanian Society for Cell Biology, 4908-4918.

Purwanto, A., Asbari, M., Hartuti, H., Setiana, Y. N., \& Fahmi, K. (2021). Effect of Psychological Capital and Authentic Leadership on Innovation Work Behavior. International Journal of Social and Management Studies, 2(1), 1-13. https://doi.org/10.5555/ijosmas.v2i1.4

Pham Thi, T. D., Ngo, A. T., Duong, N. T., \& Pham, V. K. (2021). The Influence of Organizational Culture on Employees' Satisfaction and Commitment in SMEs: A Case Study in Vietnam. The Journal of Asian Finance, Economics and Business, 8(5), 1031-1038. https://doi.org/10.13106/JAFEB.2021.VOL8.NO5.1031

Quddus, A., Nugroho, B. S., Hakim, L., Ritaudin, . M. S., Nurhasanah, E., Suarsa, . A., Karyanto, U. B., Tanjung, R., Hendar, Pratama, V. Y., Awali, H., Mufid, A., Purwanto, . A., Fahlevi, M. \& Sudargini, Y. (2020). Effect of Ecological, Servant dan Digital Leadership Style Influence University Performance? Evidence from Indonesian Universities. Systematic Reviews in Pharmacy, 11(10), 408-417. doi:10.31838/srp.2020.10.64

Rahaman, M. A., Luna, K. F., Ping, Z. L., Islam, M. S., \& Karim, M. M. (2021). Do Risk-Taking, Innovativeness, and Proactivity Affect Business Performance of SMEs? A Case Study in Bangladesh. The Journal of Asian Finance, Economics and Business, 8(5), 689-695. https://doi.org/10.13106/JAFEB.2021.VOL8.NO5.0689

Saad, A. Y. Q., \& AlsheriI, A. M. A. (2021). Measurements of Service Quality of Islamic Banking in Malaysia: A NonMalaysian Customers' Perspective. The Journal of Asian Finance, Economics and Business, 8(5), 413-420. https://doi.org/10.13106/JAFEB.2021.VOL8.NO5.0413

Singhdong, P., Suthi, K., \& PornchaiL, P. (2021). Factors Influencing Digital Transformation of Logistics Service Providers: A Case Study in Thailand. The Journal of Asian Finance, Economics and Business, 8(5), 241-251. https://doi.org/10.13106/JAFEB.2021.VOL8.NO5.0241

Suheny, E., Arum, M., Wandi, D., Rahmat, A., kurnianingsih, . A., Haerani, A., Dasmaran, V., Taryanto, , Adha, . S. \& Purwanto, A. (2020). Develop Leadership Style Model for Indonesian SMEs Leaders During Covid-19 Pandemic. Systematic Reviews in Pharmacy, 11(8), 576-586. doi:10.31838/srp.2020.8.82

Selim, H., M. (2011). Content Evaluation Criteria for General Website: Analysis and Comparison. UAE University Working Paper Series, 3, 12-28

Setiawati, N., Sunarsi, D., Nurjaya, Syaechurodji, Manan, A., Nurhadi,A., Purwanto. A. (2021). Effect of Technology Acceptance Factors, Website Service Quality and Specific Holdup Cost on Customer Loyalty: A Study in Marketing Departement of Packaging Industry. Annals of the Romanian Society for Cell Biology, 25(2), 12685-12697

Syafri, W., Prabowo, H., Nur, S. A., \& Muafi, M. (2021). The Impact of Workplace Green Behavior and Green Innovation on Green Performance of SMEs: A Case Study in Indonesia. The Journal of Asian Finance, Economics and Business, 8(5), 365-374. https://doi.org/10.13106/JAFEB.2021.VOL8.NO5.0365

Tan, J. D., Sugiarto, S., \& Budhijono, F. (2021). Family Business and Risk Management: Perspectives of SMEs Entrepreneurs in Indonesia. The Journal of Asian Finance, Economics and Business, 8(5), 851-861. https://doi.org/10.13106/JAFEB.2021.VOL8.NO5.0851

Tran, T. K. P., \& Truong, T. T. (2021). Impact of Servant Leadership on Public Service Motivation of Civil Servants: Empirical Evidence from Vietnam. The Journal of Asian Finance, Economics and Business, 8(4), 1057-1066. https://doi.org/10.13106/JAFEB.2021.VOL8.NO4.1057

Yunarsih, N., Rahayu, S., Fatoni, , Asra, ., Sustiyono, . A., Anwar, T., Sri, N. \& Purwanto, A. (2020) Develop Leadership Style Model for Nurse in Indonesian Hospital. Systematic Reviews in Pharmacy, 11(8), 352-361. doi: $10.31838 /$ srp. 2020.8 .53

Wanasida, A. S., Bernarto, I., Sudibjo, N., \& Purwanto, A. (2021). The Role of Business Capabilities in Supporting Organization Agility and Performance During the COVID-19 Pandemic: An Empirical Study in Indonesia. The Journal of Asian Finance, Economics and Business, 8(5), 897-911. https://doi.org/10.13106/JAFEB.2021.VOL8.NO5.0897

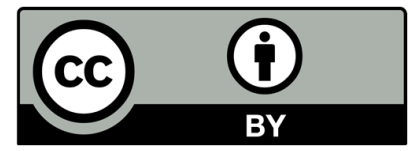

(C) 2021 by the authors; licensee Growing Science, Canada. This is an open access article distributed under the terms and conditions of the Creative Commons Attribution (CC-BY) license (http://creativecommons.org/licenses/by/4.0/). 